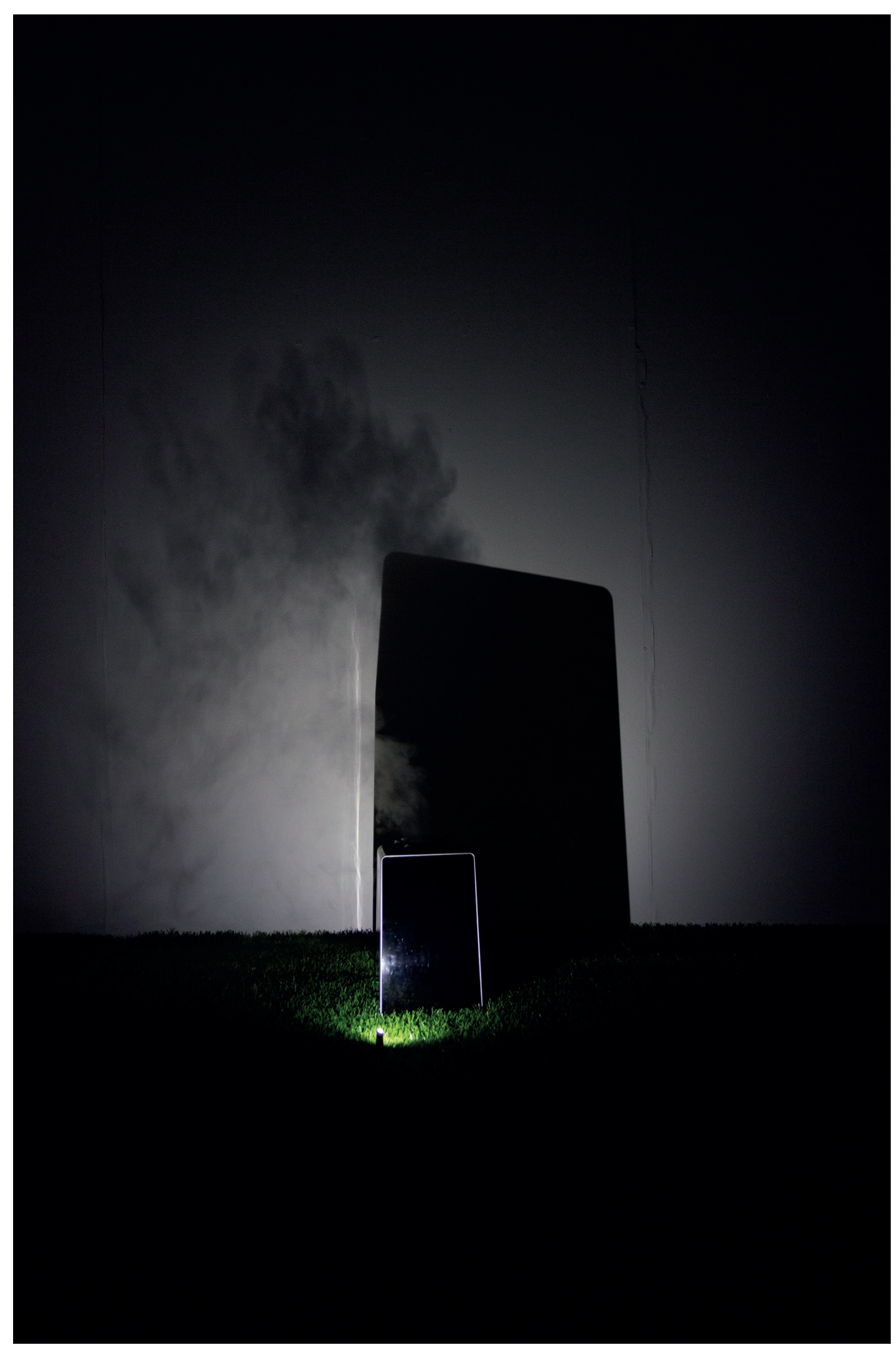



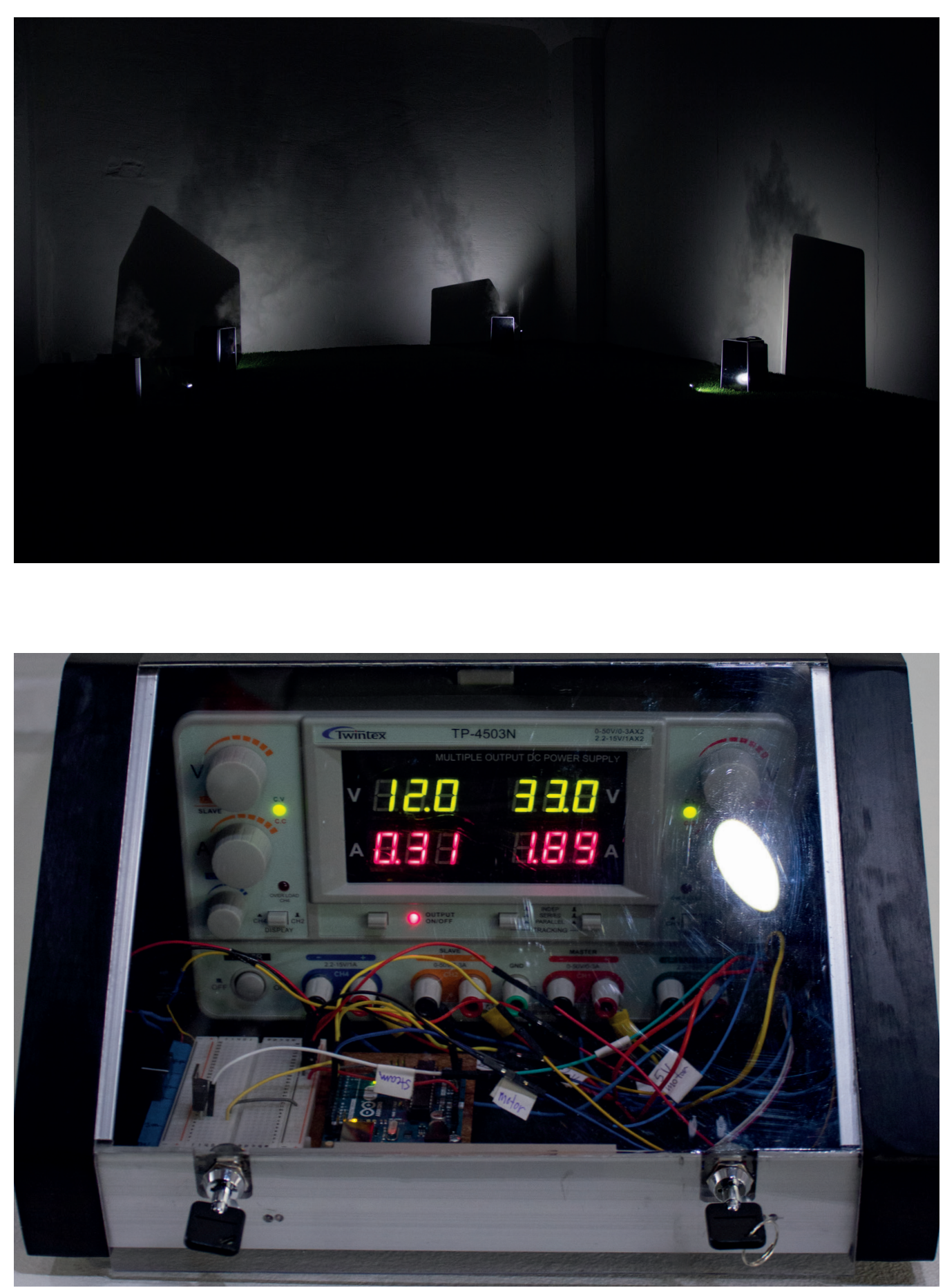

LAURA DAHLBERG: $\mathrm{C}_{6} \mathrm{H}_{12} \mathrm{O}$ (2018). ILMANKOSTUTTIMET, LIIKETUNNISTIMET, ULKOINEN VIRTALÄHDE, ARDUINO, LED- VALOT, VASTALEIKATUN NURMIKON TUOKSU, TEKONURMIMATTO. KUVAT LAURA DAHLBERG. 


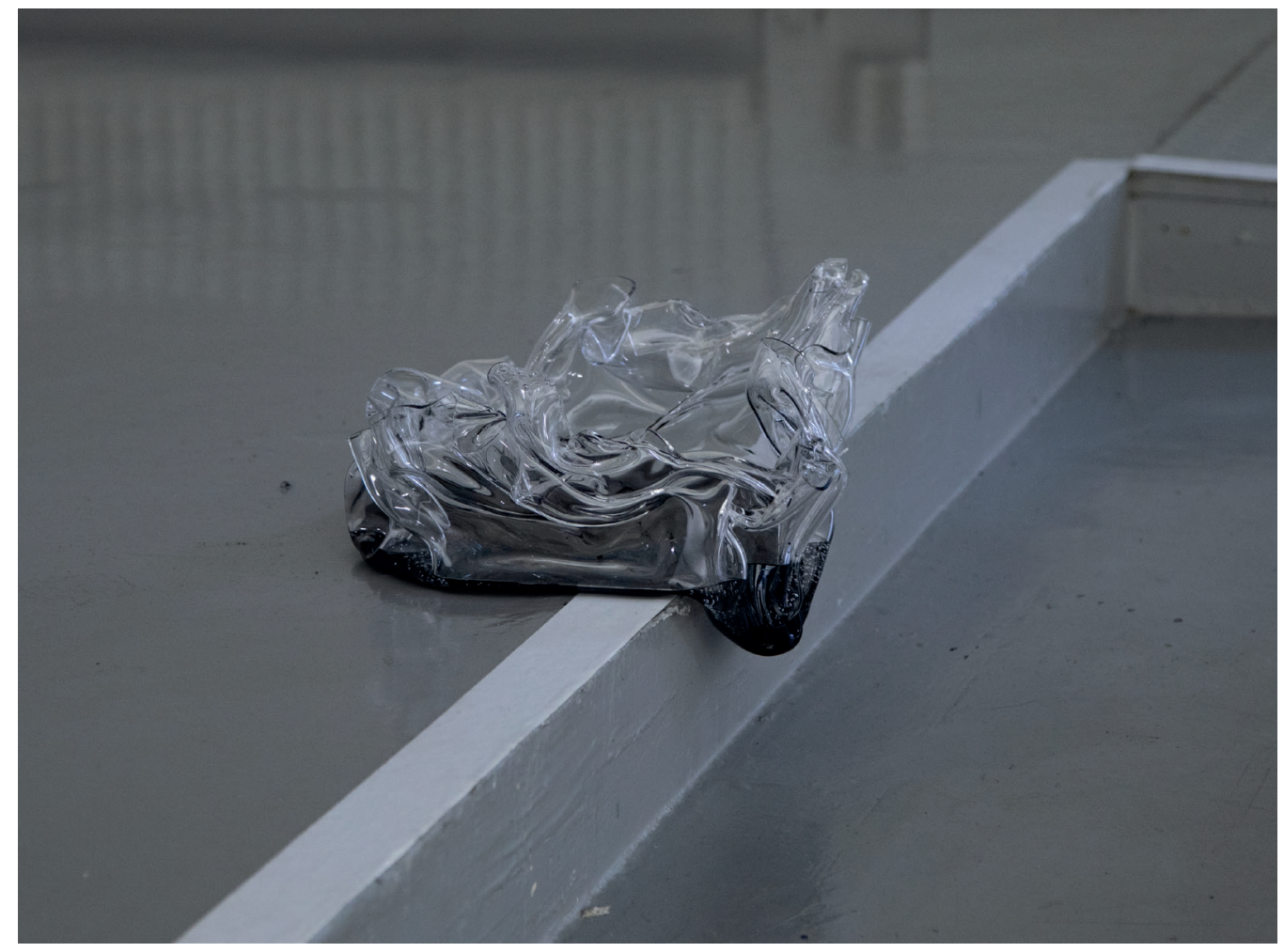




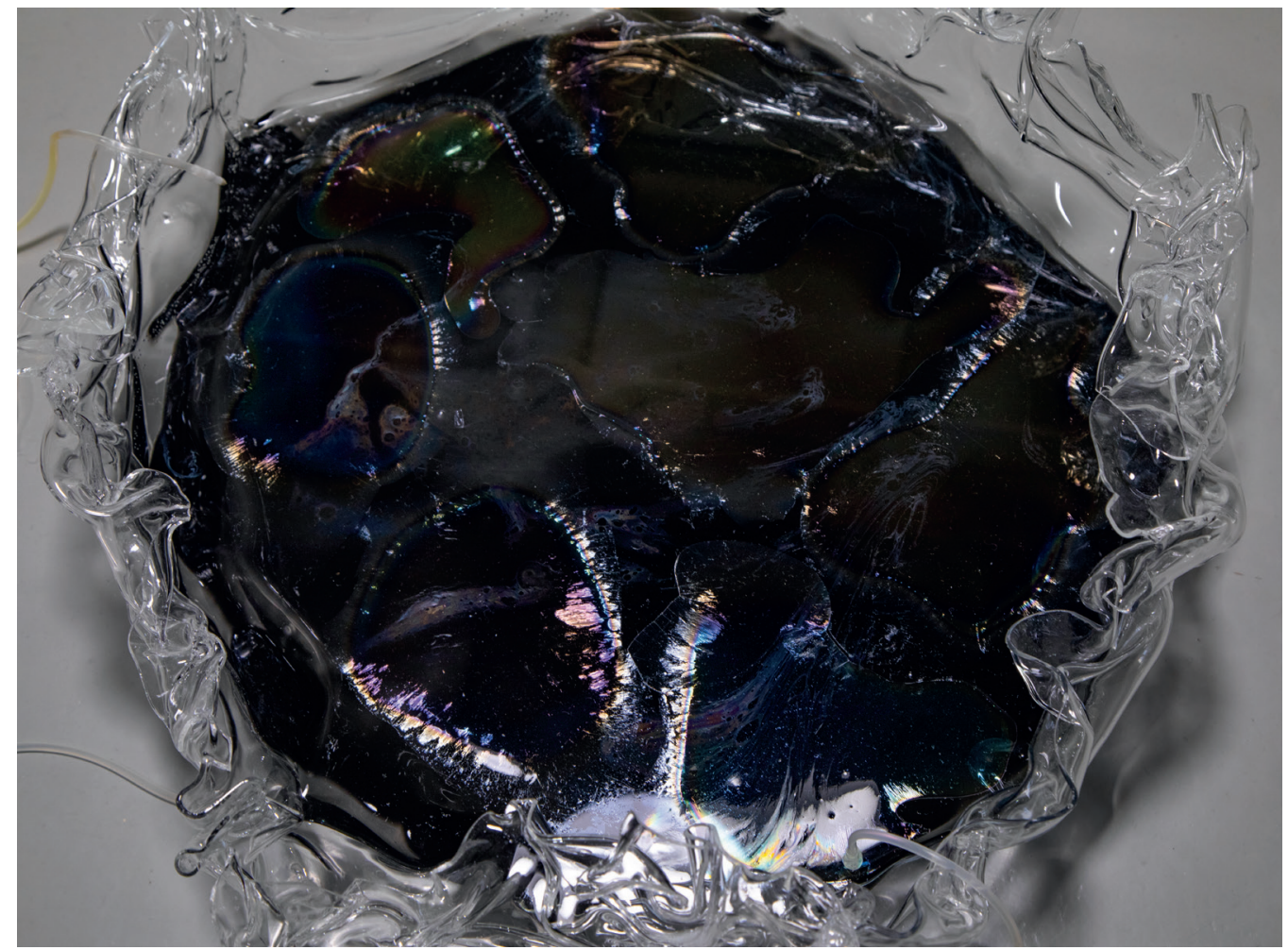

LAURA DAHLBERG: KOKEMUSAINE (2020). AKRYYLIMUOVI, LUUMUSTA-PIGMENTILLÄ VÄRJÄTTY EPOKSILAKKA, VESI, MOOTTORIÖLJY, LAKKA, TIPPALETKUT, NÄYTÖT, VIDEOT, NESTEPUMPPU, ARDUINO, KIRKASVALOLAMPUT. KUVAT LAURA DAHLBERG. 


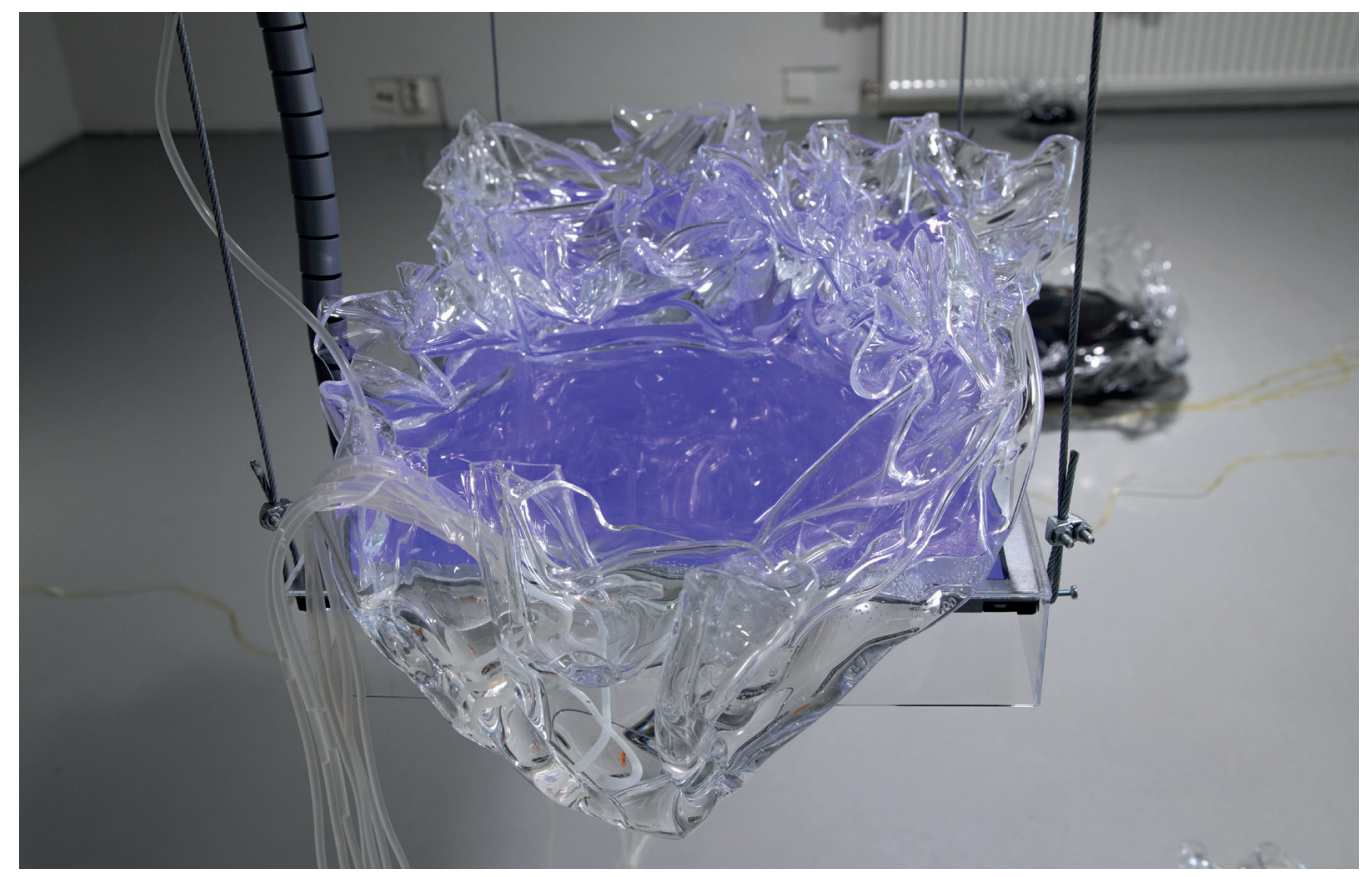




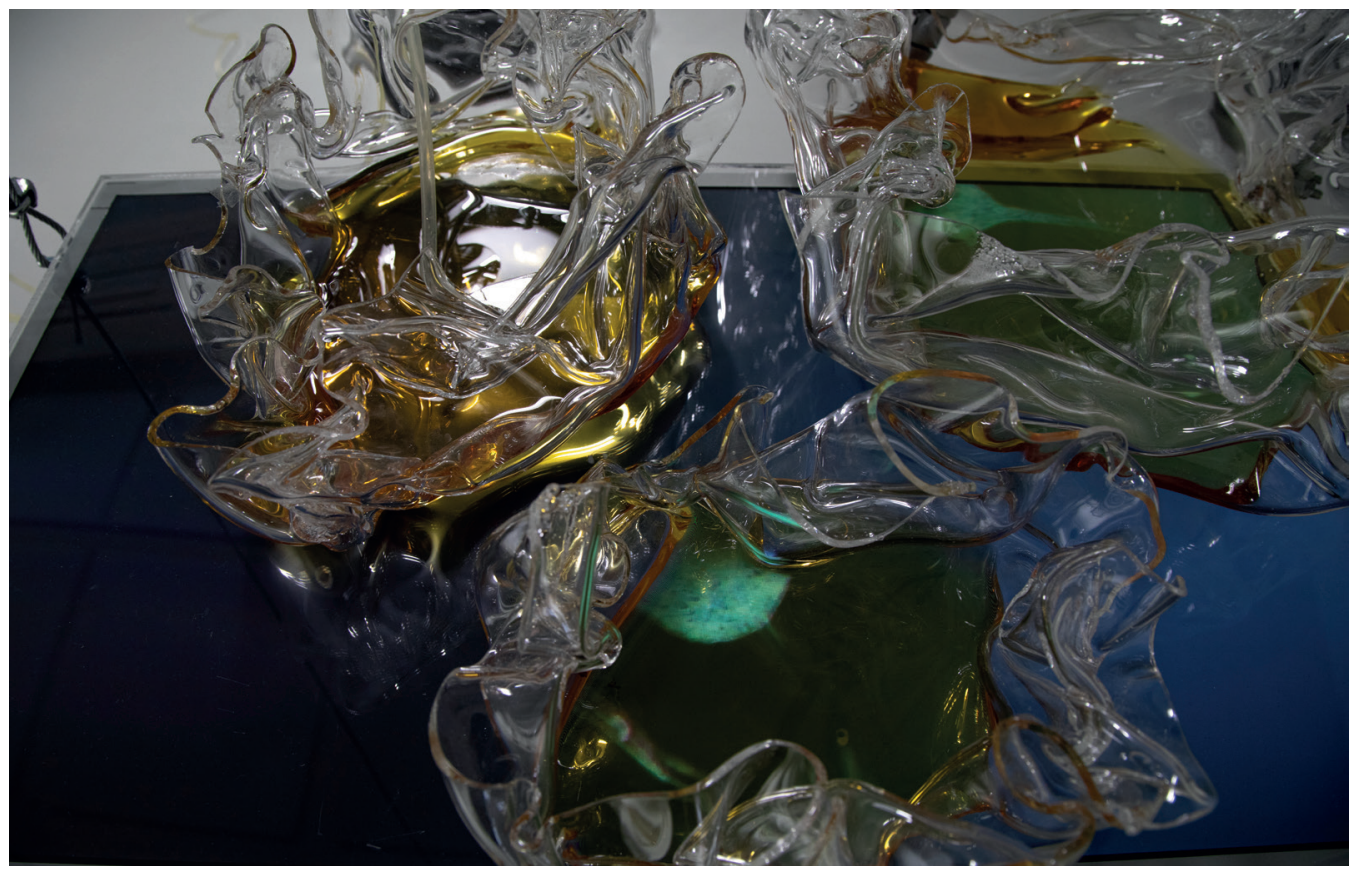




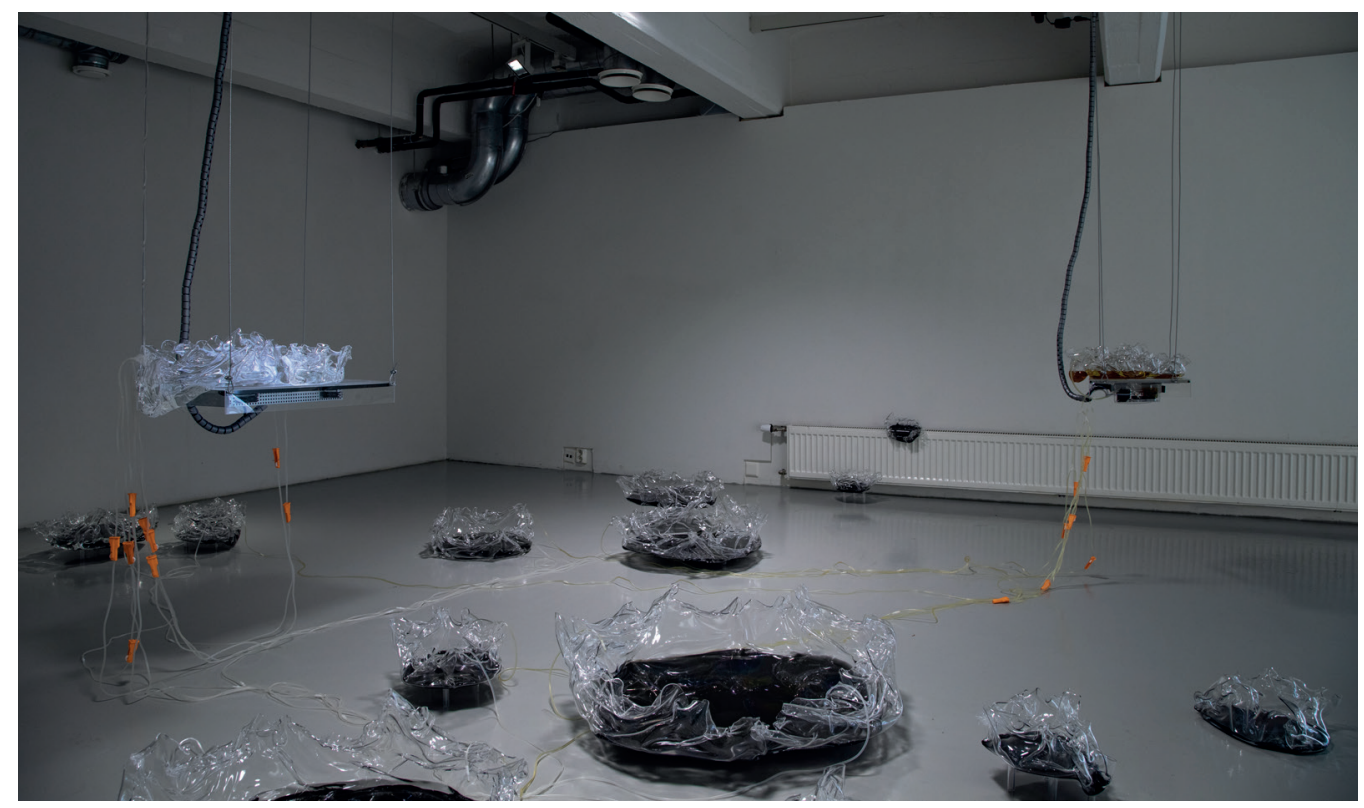




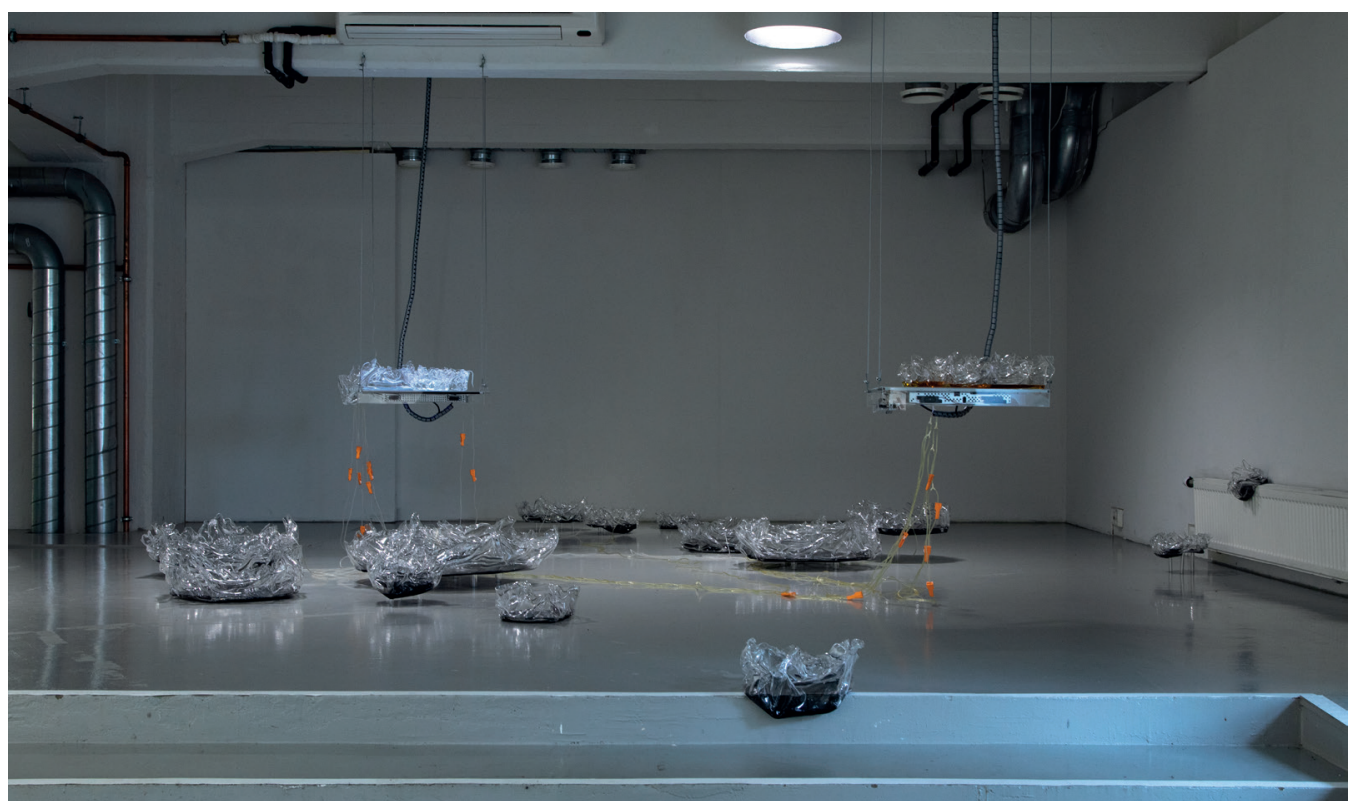

LAURA DAHLBERG: KOKEMUSAINE (2020). AKRYYLIMUOVI, LUUMUSTA-PIGMENTILLÄ VÄRJÄTTY EPOKSILAKKA, VESI, MOOTTORIÖLJY, LAKKA, TIPPALETKUT, NÄYTÖT, VIDEOT, NESTEPUMPPU, ARDUINO, KIRKASVALOLAMPUT. KUVAT LAURA DAHLBERG. 


\section{LAURA DAHLBERG}

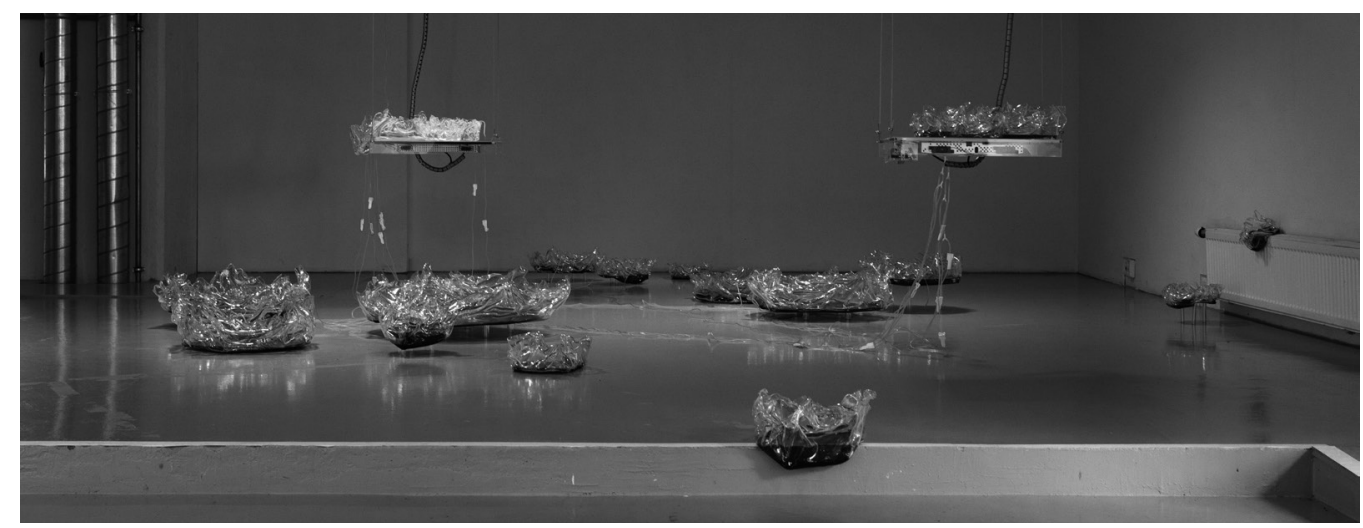

Ymmärsin sen määrittelevän enemmän meitä kuin me sitä.

Olosubteemme riippuvat siitä, sen energiavoima on ylivoimaista.

Kokemuksemme siitä on välillinen.

Joskus se tuoksuu autotallilta, on kullankeltaista ja oleilee kauniisti veden pinnalla.

\section{Millainen on sen kokemus meistä?}

Sen alkuperä on kuitenkin joskus ollut elävää, se on auringon varastoitunutta energiaa, nykyajan alkuainetta.

KUVAN KEVÄT 2020 -KATALOGITEKSTI KOKEMUSAINE-TEOKSELLE

$$
*
$$

Tutkin taiteellisessa työskentelyssäni tapoja, joilla voisimme kokea yhteiselon merkitystä koneiden, materian ja muiden lajien kesken. Nykyisen pandemian myötä olen pohtinut uudenlaisesta näkökulmasta ihmisen suhdetta muihin lajeihin. Tällä hetkellä keskuudessamme on aistien havaitsemattomissa oleva virus, joka määrittää elämänehtoja samalla tavoin kuin mekin olemme määritelleet niin monen lajin elämänehtoja ennen sitä. Mitä tämä outo yhteiselo ja vastavuoroisuus voisi meille opettaa?

Pyrin työskentelyssäni luomaan tiloja, joissa erilaiset aistiärsykkeet luovat yhteyksiä katsojan ja muun maailman välillä. Installaationi sisältävät usein mekaanista liikettä, erilaisia sensoreita sekä tuoksuja. Esimerkiksi Kokemusaine-teoksessani tutkin fossiilisen öljyn alkuperää, materiaalisuutta ja henkistä voimaa. Teoksessa $\mathrm{C}_{6} \mathrm{H}_{12} \mathrm{O}$ tutkin aistiärsykkeiden tuomaa informaatiota ympäristömme tilasta. 
Kokemusaine on kokeellinen muotokuva öljystä. Teoksen nimi viittaa Antti Salmisen ja Tere Vadénin kehittämään termiin, jolla he kuvaavat öljyn erottamatonta osaa nykyihmisen identiteetissä ja käsityksessä ympäröivästä maailmasta. Teosta toteuttaessani pohdin myös animististen maailmankuvien kykyä huomioida toimijuus luonnonelementeissä: voisiko tämä aine olla kuin animistinen jumaluus, jonka voima ja symbioosi nykyihmisen kanssa tarvitsisi lepyttelyä nykyisessä tilanteessamme? Teoksen visuaalisena lähtökohtana on irisoiva efekti, joka syntyy öljyn muodostaessa ohuen kalvon vedenpinnalla. Valon taittuessa kalvon pinnalta öljy havaitaan prisman kaikkina väreinä. Käyttämieni materiaalien kautta tarkastelen myös öljyn ja veden yhteyttä. Vesi on ollut muinaisten orgaanisten fossiilien elinehto, mutta nyt fossiilisen öljyn ja veden sekoittuminen on tuhoavaa.

Myös erilaiset aistikokemukset ovat taiteellisen työskentelyni keskiössä. Teoksessani $\mathrm{C}_{6} \mathrm{H}_{12} \mathrm{O}$ tutkin keinotekoisuuden ja luonnollisuuden suhdetta tuoksujen avulla. Installaatiossa luonnon kasvistoa imitoiva muovinen ruohomatto yhdistyy ilmankostuttimien luomaan teolliseen maisemaan. Ilmankostuttimien vesihöyry levittää hämärään tilaan kemistin valmistamaa synteettistä ruohontuoksua. Höyryn varjojen hitaan liikkeen ja ruohontuoksun on tarkoitus luoda rauhoittava tila, jossa aistien tuomaa informaatiota on helpompi tarkastella. Mit $\ddot{a}$ esimerkiksi hajuaisti voi kertoa meille ympäristömme tilasta tai sen muista toimijoista?

Kokemus kuluneesta pandemiavuodesta on ollut kaikessa outoudessaan pysäyttävä. Kuten öljyn ja ihmisen suhteessa, myös voimakkaan viruksen aikaansaamassa tilanteessa pääsemme jonkun olennaisen äärelle. Kuten öljyn voidaan ajatella olevan luonnonjumaluuden kaltainen, voisiko myös virus olla sellainen? Tarvitsisiko myös tämä olento ihmisen lepyttelyä ja arvonantoa sen lisäksi, että yritämme poistaa sen nopeasti keskuudestamme?

Laura Dahlberg on kuvataiteilija, joka viimeistelee maisterintutkintoaan Taideyliopiston Kuvataideakatemiassa.Häntä inspiroi taiteen tekemisessä kokeellisuus, uudet materiaalit ja aistikokemukset. Dahlberg on kiinnostunut tieteen ja taiteen yhdistämisestä sekä uusimman teknologian mahdollisuuksista.

Tulevat näyttelyt: Project Roomissa Helsingissä kesäkuussa 2021 ja Titanik-Galleriassa Turussa lokakuussa 2021.

Lisätietoa www.lauradahlberg.com 